\title{
Reproduction in a polluted world: implications for wildlife
}

\author{
Lucinda C Aulsebrook ${ }^{1}$, Michael G Bertram ${ }^{1,2}$, Jake M Martin¹, Anne E Aulsebrook ${ }^{3}$, \\ Tomas Brodin ${ }^{2}$, Jonathan P Evans ${ }^{4}$, Matthew D Hall ${ }^{1}$, Moira K O'Bryan ${ }^{1}$, Andrew J Pask ${ }^{3}$, \\ Charles R Tyler ${ }^{5}$ and Bob B M Wong ${ }^{1}$ \\ ${ }^{1}$ School of Biological Sciences, Monash University, Victoria, Australia, ${ }^{2}$ Department of Wildlife, Fish, and \\ Environmental Studies, Swedish University of Agricultural Sciences, Umeå, Sweden, ${ }^{3}$ School of BioSciences, The \\ University of Melbourne, Victoria, Australia, ${ }^{4}$ School of Biological Sciences, The University of Western Australia, \\ Perth, Australia and ${ }^{5}$ Biosciences, College of Life and Environmental Sciences, University of Exeter, Exeter, UK
}

Correspondence should be addressed to L C Aulsebrook; Email: lucinda.aulsebrook@monash.edu

\begin{abstract}
Environmental pollution is an increasing problem for wildlife globally. Animals are confronted with many different forms of pollution, including chemicals, light, noise, and heat, and these can disrupt critical biological processes such as reproduction. Impacts on reproductive processes can dramatically reduce the number and quality of offspring produced by exposed individuals, and this can have further repercussions on the ecology and evolution of affected populations. Here, we illustrate how environmental pollutants can affect various components of reproduction in wildlife, including direct impacts on reproductive physiology and development, consequences for gamete quality and function, as well as effects on sexual communication, sexual selection, and parental care. We follow with a discussion of the broader ecological and evolutionary consequences of these effects on reproduction and suggest future directions that may enable us to better understand and address the effects of environmental pollution.

Reproduction (2020) 160 R13-R23
\end{abstract}

\section{Introduction}

Environments around the globe are changing at an unprecedented pace and scale as a result of pollution from human activities. In this regard, wildlife are confronted with anthropogenic pollution in a wide variety of forms. This includes chemical contaminants that enter the environment from the manufacture, usage, and disposal of myriad products, such as pesticides, pharmaceuticals, and heavy metals (Dixit et al. 2015, Bernhardt et al. 2017). Other pollution sources include widespread anthropogenic light sources that illuminate the night (Longcore \& Rich 2004), noise that is propagated throughout environmental landscapes from traffic, machinery, and industrial activities (Barber et al. 2011), and heat pollution, both local and global, that alters thermal niches within ecosystems (Hansen et al. 2006, Yow 2007). These diverse forms of pollution can all have detrimental effects on wildlife and the ecological communities they inhabit.

A particularly concerning consequence of environmental pollution is the disruption of reproductive processes. Pollutants can interfere with a broad range of traits necessary for reproductive success, such as reproductive physiology, gamete function, and organismal behaviour (Table 1). Alteration of these processes can reduce mating success, either directly by decreasing fertilisations or indirectly by disrupting mate attraction and/or encounter rates. These effects can dramatically alter the number and quality of offspring that individuals can contribute to successive generations, a concept commonly referred to as the 'fitness' of an individual (Orr 2009). These changes in fitness can then have harmful repercussions at the population and community levels, as well as influence the evolutionary trajectories of affected populations. Despite being essential for understanding how species will be affected by human-induced environmental change, the ecological and evolutionary repercussions of pollutants are rarely considered (but see Saaristo et al. 2018). Additionally, most studies focus on the direct effects of a single pollutant on a single species, limiting our understanding of how biotic and abiotic interactions influence the broader impacts of pollution.

In this review, we illustrate the ways in which reproduction can be impacted by environmental pollution and discuss the ecological and evolutionary consequences of these effects. We begin by outlining the direct impacts of environmental pollution on reproductive physiology and development, such as pollutioninduced changes in sex hormones/pheromones, sex differentiation, and reproductive timing. We then consider how pollution can affect gamete production and function, including sperm motility and egg viability, 
Table 1 Summary table of examples featured in this review to illustrate the different effects environmental pollution can have on reproductive function across diverse taxa.

\begin{tabular}{|c|c|c|c|c|}
\hline Effect & Pollutant & Source of pollutant & Animal & Paper \\
\hline \multirow[t]{3}{*}{ Feminisation of males } & Ethinyloestradiol & Contraceptive pill & $\begin{array}{l}\text { Fish (Rutilus rutilus, Pimephales } \\
\text { promelas) }\end{array}$ & $\begin{array}{l}\text { Jobling et al. (1998), Kidd et al. } \\
\text { (2007), Lange et al. (2009) }\end{array}$ \\
\hline & \multirow[t]{2}{*}{ Atrazine } & \multirow[t]{2}{*}{ Herbicide } & $\begin{array}{l}\text { Amphibians (Xenopus laevis, } \\
\text { Rana pipiens) }\end{array}$ & $\begin{array}{l}\text { Hayes et al. (2002a,b, 2003, } \\
\text { 2006, 2010) }\end{array}$ \\
\hline & & & Mice (Mus musculus) & $\begin{array}{l}\text { Cook et al. (2019), Govers } \\
\text { et al. (2019) }\end{array}$ \\
\hline $\begin{array}{l}\text { Masculinisation of } \\
\text { females }\end{array}$ & Tributyltin (TBT) & Anti-fouling paint & Gastropods (various species) & $\begin{array}{l}\text { Ten Hallers-Tjabbes et al. } \\
\text { (1994), Matthiessen and } \\
\text { Gibbs (1998) }\end{array}$ \\
\hline \multirow[t]{2}{*}{$\begin{array}{l}\text { Disruption of gonad } \\
\text { development }\end{array}$} & Neonicotinoids & Insecticide & $\begin{array}{l}\text { Bumblebees (Bombus terrestris, } \\
\text { B. lucorum, B. pratorum, } \\
\text { B. pascuorum) }\end{array}$ & Baron et al. (2017) \\
\hline & Heat & $\begin{array}{l}\text { Global warming, heat islands, } \\
\text { factory discharge, and so on }\end{array}$ & Fish (Rutilus rutilus) & $\begin{array}{l}\text { Luksiene and Sandström } \\
\text { (1994) }\end{array}$ \\
\hline \multirow[t]{4}{*}{ Biased sex ratios } & Heat & $\begin{array}{l}\text { Global warming, heat islands, } \\
\text { factory discharge, and so on }\end{array}$ & Sea turtles (various species) & Fuentes et al. (2009) \\
\hline & Clotrimazole & Antifungal & Zebrafish (Danio rerio) & Brown et al. (2015) \\
\hline & Dieldrin & Insecticide & Daphnia galeata & Dodson et al. (1999a) \\
\hline & Atrazine & Herbicide & Daphnia pulicaria & Dodson et al. (1999b) \\
\hline \multirow{3}{*}{$\begin{array}{l}\text { Altered reproductive } \\
\text { timing }\end{array}$} & Light & Artificial lighting from & Blackbirds (Turdus merula) & Dominoni et al. $(2013 a, b)$ \\
\hline & & $\begin{array}{l}\text { streetlights, building exteriors, } \\
\text { advertising, and so on }\end{array}$ & $\begin{array}{l}\text { Tammar wallabies } \\
\text { (Macropus eugenii) }\end{array}$ & Robert et al. (2015) \\
\hline & Heat & $\begin{array}{l}\text { Global warming, heat islands, } \\
\text { factory discharge, and so on }\end{array}$ & Birds (Parus major) & Visser et al. (2009) \\
\hline \multirow{3}{*}{$\begin{array}{l}\text { Reduced sperm } \\
\text { motility }\end{array}$} & Bisphenol A (BPA) & Plastic production & Brown trout (Salmo trutta) & Lahnsteiner et al. (2005) \\
\hline & Air particulates & Smoke, fumes, and so on & Humans & $\begin{array}{l}\text { Deng et al. (2016), Jurewicz } \\
\text { et al. (2018) }\end{array}$ \\
\hline & Radiation & Nuclear accidents & Birds (Hirundo rustica) & $\begin{array}{l}\text { Møller et al. (2005, 2008, } \\
\text { 2014) }\end{array}$ \\
\hline \multirow{2}{*}{$\begin{array}{l}\text { Decreased } \\
\text { fertilisation success } \\
\text { of eggs }\end{array}$} & Titanium dioxide & Personal care products & Bivalves (Tegillarca granosa) & Han et al. (2019) \\
\hline & Heavy metals & $\begin{array}{l}\text { Mining, products such as } \\
\text { fertilisers, batteries, and so on }\end{array}$ & Fish (various species) & Jezierska et al. (2009) \\
\hline \multirow[t]{3}{*}{$\begin{array}{l}\text { Inhibited pheromone } \\
\text { production }\end{array}$} & Diclofop-methyl & Herbicide & $\begin{array}{l}\text { Cotton bollworm moth } \\
\text { (Helicoverpa armigera) }\end{array}$ & Eliyahu et al. (2003) \\
\hline & Light & $\begin{array}{l}\text { Artificial lighting from } \\
\text { streetlights, building exteriors, } \\
\text { advertising, and so on }\end{array}$ & $\begin{array}{l}\text { Cabbage moths } \\
\text { (Mamestra brassicae) }\end{array}$ & van Geffen et al. (2015) \\
\hline & Endosulfan & Insecticide & $\begin{array}{l}\text { Red-spotted newts } \\
\text { (Notophthalmus viridescens) }\end{array}$ & Park et al. (2001) \\
\hline \multirow[t]{2}{*}{$\begin{array}{l}\text { Masked mating } \\
\text { signals }\end{array}$} & Noise & $\begin{array}{l}\text { Traffic, industrial activities, and } \\
\text { so on }\end{array}$ & $\begin{array}{l}\text { Fish, amphibians, birds and } \\
\text { mammals (various species) }\end{array}$ & Shannon et al. (2016) \\
\hline & Light & $\begin{array}{l}\text { Artificial lighting from } \\
\text { streetlights, building exteriors, } \\
\text { advertising, and so on }\end{array}$ & $\begin{array}{l}\text { Glow-worms } \\
\text { (Lampyris noctiluca) }\end{array}$ & Bird and Parker (2014) \\
\hline \multirow{2}{*}{$\begin{array}{l}\text { Disrupted mate } \\
\text { choice }\end{array}$} & Trenbolone & Agricultural growth-promotant & Guppies (Poecilia reticulata) & Tomkins et al. (2018) \\
\hline & Ethinyloestradiol & Contraceptive pill & $\begin{array}{l}\text { European Starlings } \\
\text { (Sturnus vulgaris) }\end{array}$ & Markman et al. (2008) \\
\hline $\begin{array}{l}\text { Reduced parental } \\
\text { care }\end{array}$ & Noise, light & $\begin{array}{l}\text { Traffic, industrial activities, } \\
\text { artificial lighting from } \\
\text { streetlights, building exteriors, } \\
\text { advertising, and so on }\end{array}$ & Seabirds (Calonectris diomedea) & $\begin{array}{l}\text { Cianchetti-Benedetti } \\
\text { et al. (2018) }\end{array}$ \\
\hline
\end{tabular}

before going on to examine impacts of pollution on reproductive processes such as sexual communication and mate choice. This is followed by a discussion of the ecological and evolutionary repercussions of these effects on reproduction. We conclude by highlighting future directions and steps necessary to understand and address the realised effects of environmental pollution on reproduction.

\section{Direct effects of pollution on reproductive physiology and development}

Environmental pollution can fundamentally affect reproduction by altering the production or signalling efficacy of sex hormones. A variety of chemical pollutants, for instance, can interact with steroid hormone receptors directly or indirectly, altering levels of blood sex steroids 
and disrupting sexual development. Such chemicals are collectively referred to as endocrine-disrupting chemicals (EDCs). For example, ethinyloestradiol, an oestrogen commonly used in contraceptive pills, can enter the environment via urine (Johnson \& Williams 2004) and has been shown to induce physiological feminisation in wild fish through its interaction with oestrogen receptors (Jobling et al. 1998, Lange et al. 2009). Various other chemical pollutants that mimic endogenous steroids are also known to interact directly with oestrogen receptors (e.g. bisphenol A: Gould et al. 1998; phthalates: Jobling et al. 1995) and androgen receptors (e.g. the livestock growth promoter trenbolone: Sone et al. 2005; various prostate chemotherapeutic agents: Mateo et al. 2014), with downstream consequences for reproductive physiology. Pollutants can also change sex hormone levels via stress-related mechanisms or through effects on other hormonal pathways (Brüning et al. 2016). Indeed, there is evidence that light pollution can act as a chronic stressor, inhibiting the production of sex hormones in birds via the hypothalamic-pituitary-adrenal axis (Russ et al. 2015).

Such changes in sex hormone levels can have repercussions for the development of reproductive anatomy and morphology in organisms. For example, in Lake Apopka, Florida, exposure of American alligators (Alligator mississippiensis) to a mixture of chemicals - including a spill of dicofol and DDT, agricultural runoff such as pesticides, and sewage treatment outflow - resulted in females exhibiting abnormal ovarian morphology and unusually prominent polyovular follicles, while males developed poorly organised testes and small phalli (Guillette et al. 1994, 1995, 1996). Further, developmental exposure of amphibians to the widespread herbicide atrazine has been shown to induce reproductive malformations due to feminisation of males. This includes the anomalous development of multiple gonads (Hayes et al. 2002a), altered testicular anatomy (Tavera-Mendoza et al. 2002, Hayes et al. 2003), development of ovotestes and testicular oocytes (Hayes et al. 2006, 2010, Murphy et al. 2006) and hermaphroditism (Hayes et al. 2002a,b). Atrazine can also lead to feminisation in mice, resulting in penis abnormalities (Govers et al. 2019) and altered sperm production (Cook et al. 2019). The direct impacts of chemical pollution on reproductive anatomy and morphology have been reported across a diverse array of taxa (e.g. feminisation of fish populations exposed to oestrogenic chemicals: Jobling et al. 1998, 2006; masculinisation of gastropods exposed to anti-fouling paint: Ten Hallers-Tjabbes et al. 1994, Matthiessen \& Gibbs 1998; reduced ovary development in neonicotinoid-exposed wild bumblebee queens: Baron et al. 2017), providing evidence that chemical pollution could be a major driver in the reported increases in abnormalities seen in sexual development in humans (discussed in Giwercman et al. 1993, Skakkebæk et al. 2001, Damgaard et al. 2002).

Direct effects of pollution on wildlife reproductive anatomy and morphology are not limited to impacts of chemical pollution. Indeed, thermal pollution from nuclear power plants has been associated with altered gonad growth and asynchronic gonad and oocyte development in fish populations (Luksiene \& Sandström 1994). Further, thermal pollution exposure has been shown to result in a greater variation in gonad development, both within and among fish populations (Efimova 1977, Virbickas et al. 1981, Lapina 1991, Luksiene \& Sandström 1994). While few studies have investigated the impacts of noise pollution on wildlife reproductive morphology, long-term (60 days) exposure to noise pollution has been shown to cause a decrease in the diameter of seminiferous tubules and the thickness of the germinal epithelium in adult male rats (Farzadinia et al. 2016).

In addition to altering sexual morphology, pollution can disrupt cueing systems for sex determination and/ or sexual differentiation, resulting in biased sex ratios. This is best illustrated in species that show temperaturedependent sex determination, including various fish, amphibian, and reptile species (Crews et al. 1994, Baroiller \& D'Cotta 2001, Eggert 2004). Shifts in environmental temperatures are occurring globally through climate change (Hansen et al. 2006), as well as more locally through processes such as warm water discharge into rivers and estuaries from power plants (Raptis et al. 2016). An example of the former is seen in sea turtles, where higher nest temperatures are shown to skew sex ratios towards females (Fuentes et al. 2009), and this imbalance is predicted to become more extreme as temperatures increase due to global warming. Additionally, changes in environmental temperature can exacerbate the reproductive effects of certain chemical pollutants that affect sexual differentiation. For example, the antifungal chemical clotrimazole has been shown to skew sex ratios in zebrafish (Danio rerio) towards males by inhibiting production of aromatase, an enzyme that converts testosterone to oestrogen, and this effect is enhanced at higher temperatures (Brown et al. 2015). These imbalances in sex ratios potentially reduce reproductive success by lowering encounter rates between males and females. In facultative sexual species, altered sex ratios may change the rate of sexual reproduction vs asexual reproduction. This has been seen in various Daphnia species, where the production of males can be affected by a variety of pollutants (dieldrin in Daphnia galeata: Dodson et al. 1999a; atrazine in Daphnia pulicaria: Dodson et al. 1999b; dicofol and vinclozolin in Daphnia magna: Haeba et al. 2008), altering the rate of sexual reproduction.

Exposure to environmental pollution can also alter reproductive timing in wildlife. For example, ambient 
light levels, which are used as a cue for the timing of reproductive processes in many animals, can be disrupted by light pollution. A powerful example of this is seen in common blackbirds (Turdus merula), where, after 1 year of exposure to artificial light at night, seasonal development of the birds' gonads occurred up to 1 month earlier and, after the second year of exposure, gonads did not show seasonal development at all (Dominoni et al. 2013a,b). Further, light pollution has been shown to delay births in tammar wallabies (Macropus eugenii), which is potentially mediated by suppression of melatonin (Robert et al. 2015). Ambient temperature is also used as a cue for biological events in many species, and similar to effects of artificial light pollution on reproductive timing, increased temperatures due to the effect of urban heat islands - or, more broadly, global warming - can result in temporal shifts in reproduction (Visser et al. 2009). Altered reproductive timing can have serious repercussions for offspring production or survival, as the shift may de-synchronise offspring production with peak resource availability. For example, it is predicted that, due to increasing temperatures, forest bird offspring will become increasingly mismatched with peak caterpillar availability (Burgess et al. 2018).

\section{Consequences for gametes}

The previously described effects of pollutants on hormones and sexual development can have consequences on gamete function and, hence, fertility. For example, when male fish are feminised via exposure to oestrogenic pollutants, this can result in reduced sperm quality (Jobling et al. 2002a,b). Further, female brown trout (Salmo trutta) exposed to bisphenol A (BPA) prior to, and during, spawning exhibited lower levels and later onset of ovulation, while exposed males showed reductions in sperm density, motility rate, and sperm swimming velocity (Lahnsteiner et al. 2005). These effects were likely due to the oestrogenic activity of BPA. Numerous studies have also shown that human males exposed to particulate air pollution produce sperm that exhibit impaired motility (De Rosa et al. 2003, Hammoud et al. 2010, Huang et al. 2019, see also Deng et al. 2016 for recent meta-analysis and review by Jurewicz et al. 2018) and impaired DNA structure and integrity (Sram et al. 1996, Selevan et al. 2000, Rubes et al. 2005), although the mechanisms for these effects are poorly understood. Similarly, in wildlife such as birds, radiation pollution has been shown to have a range of negative effects on sperm that include increased mutation rates, as well as reduced sperm production, quality, and motility (Møller et al. 2005, 2008, 2014).

In externally fertilising species, pollutants can induce detrimental effects through direct contact with sperm and/ or eggs. For instance, in capelin fish (Mallotus villosus), exposure to chemical-dispersing agents can reduce the fertilising capability of sperm (Beirão et al. 2018), while harmful impacts of contaminants on sperm swimming parameters have been reported in both fish (e.g. copper ions: Kowalska-Góralska et al. 2019; heavy metals: Abascal et al. 2007; EDCs: reviewed by Carnevali et al. 2018) and invertebrates (e.g. xenobiotics: Gallo 2018; nanoparticles: Hollows et al. 2007, Han et al. 2019). Pollutants can also have damaging effects through direct contact with eggs. For example, Han et al. (2019) found that in broadcast-spawning bivalves (Tegillarca granosa), the nanoscale pollutant titanium dioxide can attach to the oocyte surface and damage the plasma membrane, which is thought to contribute to reduced gamete fusion success. Similarly, in fish, exposure of spawned eggs to certain polluting metal compounds can adversely impact fertilisation capacity and general viability (Jezierska et al. 2009).

A particularly concerning aspect of certain environmental pollutants is their ability to induce longterm impacts that may persist across many generations following the initial exposure event. An increasing body of evidence has reported associations between adult exposure to environmental pollutants and reductions in offspring health and fitness, almost certainly via epigenetic mechanisms (Soubry et al. 2014). Much of this evidence comes from studies reporting changes in sperm chromatin structure, changes in sperm small ncRNA (sncRNA) content, and altered DNA methylation patterns in sperm (Evans et al. 2019). Such epigenetic changes in sperm, for example, can occur following exposure to various pollutants, including cigarette smoke (Jenkins et al. 2017), ethanol (Rompala et al. 2018) and the fungicide vinclozolin (Ben Maamar et al. 2018). Fortunately, these effects appear to be at least partially reversibly via exercise and environmental enrichment, depending on the toxicant, effect and specific process affected (Short et al. 2017). Studies have also implicated paternal chronic exposure to EDCs with changes in sperm sncRNAs. For example, in zebrafish, paternal exposure to the synthetic oestrogen $17 \alpha$-ethinyloestradiol (EE2) results in a range of disorders in offspring (e.g. skeletal and cartilage deformations, poor locomotion, etc.), mostly likely due to an up-regulation of microRNA transcripts in the testes and sperm (Valcarce et al. 2017). Such studies showing transgenerational effects suggest that environmental pollutants can impact population health long after the initial exposure and even after contaminants have been removed, which may cause us to underestimate the full scope of the impacts of such exposures.

\section{Effects of pollution on sexual communication, sexual selection, and parental care}

Pollutants can impact the ability of animals to locate potential mates by disrupting the production, transmission, and detection of signals important in sexual 
communication (Bird \& Parker 2014, Vargas-Salinas et al. 2014, Shannon et al. 2016, Walters et al. 2019). An example of this is pollution disrupting the production of pheromones - some of which are steroid hormones, such as glucuronides (Scott \& Vermeirssen 1994). For instance, in the cotton bollworm moth (Helicoverpa armigera), exposure to the herbicide diclofop-methyl has been found to inhibit sex pheromone production by reducing fatty acid synthesis (Eliyahu et al. 2003). Similarly, light pollution can disrupt pheromone production, with low-intensity artificial light at night reducing sex pheromone production in female cabbage moths (Mamestra brassicae: van Geffen et al. 2015). As these pheromones are used to indicate reproductive receptivity, inhibited pheromone production will likely reduce mate acquisition and, thus, mating success. Indeed, this has been reported in female red-spotted newts (Notophthalmus viridescens), where exposure to the insecticide endosulfan resulted in the suppression of pheromone production and subsequently reduced mating success (Park et al. 2001).

As well as disrupting pheromone production, environmental pollution can interfere with acoustic or visual signals used for sexual communication. For example, exposure to polychlorinated biphenyls (PCBs) can reduce androgen-dependent growth in cartilage and muscle of the larynx in male African clawed frogs (Xenopus laevis), preventing them from making advertisement calls to females (Qin et al. 2007). Similarly, in species as taxonomically diverse as fish, amphibians, birds, and mammals, anthropogenic noise pollution can mask acoustic signals used by individuals to attract their mates (reviewed in Shannon et al. 2016) or prevent the perception of these mating signals by damaging auditory organs (Jepson et al. 2003, André et al. 2011). Likewise, artificial light pollution is thought to be the primary driver for population declines in glow-worms (Lampyris noctiluca), as light pollution can drastically reduce the ability of males to detect the bioluminescent light signals of reproductively active females (Bird \& Parker 2014).

Environmental pollution can also compromise the ability of animals to select a suitable mate (reviewed in Candolin \& Wong 2019). For example, in a freshwater fish, the guppy (Poecilia reticulata), exposure to an agricultural steroid pollutant ( $17 \beta$-trenbolone) disrupted patterns of female preference for male colour traits that are important in signalling male genetic quality to choosy females (Tomkins et al. 2018). Exposure to pollution can also affect the relationship between the expression of sexual traits and the fitness benefits associated with those traits. In European starlings (Sturnus vulgaris), for instance, males exposed to a mixture of synthetic oestrogenic endocrine disruptors showed a reduction in immune function, but developed songs that were longer and more complex and, as a result, were actually preferred by females (Markman et al. 2008). At its most extreme, the disruption of mate selection can even lead to the breakdown of premating reproductive isolation and the loss of biodiversity. For example, in two co-occurring species of swordtail fishes (Xiphophorus birchmanni and Xiphophorus malinche), exposure to sewage effluent and agricultural runoff resulted in the loss of female preference for the odour cues of male conspecifics, leading to females mating indiscriminately with males of both species (Fisher et al. 2006).

After mating, environmental pollution can impact the quality of parental care provided to young, with consequences for the health and survival of offspring (Wong et al. 2012, Suárez-Rodríguez \& Garcia 2017, Cianchetti-Benedetti et al. 2018). For example, in seabird nesting colonies (Calonectris diomedea), shortterm nocturnal exposure to light and noise pollution has been associated with decreased weight gain of chicks, which is thought to result from a reduction in parental nest attendance and feeding (Cianchetti-Benedetti et al. 2018). Further, human-induced eutrophication and associated algal blooms have been shown to directly impact the quality of nest construction in a fish, the three-spined stickleback (Gasterosteus aculeatus), with nest quality being an important predictor of offspring survival (Wong et al. 2012). A complex example of pollution-induced effects on parental care is seen in urban-dwelling house finches (Carpodacus mexicanus) that have started to incorporate cigarette butts into the lining of their nests (Suárez-Rodríguez \& Garcia 2017). In so doing, the chemicals present in the cigarettes reduced the amount of ectoparasites in the nest, although the benefits of this behaviour may be counterbalanced in the long-term by genotoxic damage to offspring (Suárez-Rodríguez \& Garcia 2017).

\section{Ecological and evolutionary implications}

We have described how environmental pollution can impact reproductive processes in a broad variety of ways, including via direct effects on sexual development and effects on sexual selection processes. These effects on different aspects of reproduction can dramatically alter the fitness of individuals by reducing the quality and/or quantity of offspring produced. By disrupting the overall reproductive success of a population, environmental pollution has many implications for the viability and evolutionary trajectory of affected populations.

Many of the reproductive alterations outlined in this review decrease fitness as a result of reduced mating or fertilisation success. In some cases, pollution-exposed individuals have reduced fertility due to impaired sexual development and/or gamete function. In other cases, individuals are unable to locate a mate due to the disruption of the production, transmission, or detection or sexual communication signals. As population stability depends on new generations of offspring, lowered reproductive success resulting from pollution exposure may lead to population declines or even extinctions. 
For example, Kidd et al. (2007) conducted a 7-year whole-lake experiment with chronic exposure of fathead minnows (Pimephales promelas) to low concentrations of $17 \alpha$-ethinyloestradiol (EE2). The resulting feminisation of males and altered oogenesis in females led to a near extinction of this species in the lake, demonstrating the extreme impacts that reproductive impairment due to pollution can have at the population level (see also Desforges et al. 2018).

Effects of pollution on reproductive traits, however, do not always lower organismal fitness. Some alterations in reproductive processes may be minor enough to have negligible effects on fitness. For example, De Jong et al. (2015) reported that exposure to light pollution affected the lay date of great tits, although this did not appear to have any measurable fitness consequences in the offspring. Additionally, where pollutants cause the sex ratio of a population to be skewed towards females, this may not significantly affect the growth of a population in cases where the males are still able to successfully fertilise most of the females (Candolin 2019). In other cases, certain pollutants have even been shown to have potentially positive effects on fitness. For example, male fish exposed to growth-promoting steroids have been found to perform more copulations than unexposed males (Bertram et al. 2015, 2018). Similarly, Daphnia magna have been found to have increased fecundity when exposed to fluoxetine, an ingredient of many antidepressant medications (Campos et al. 2012). Together, the previously mentioned examples highlight how pollution can have negative, negligible, and even potentially positive effects on the average reproductive success of individuals within a population, with clear implications for population persistence over time.

In some cases, populations may be able to adjust or adapt to reproductive challenges posed by pollution, either through plastic or evolved responses. For example, city-dwelling song birds sing at a higher pitch compared to rural conspecifics, so that they can be heard above the low frequency din of urban noise (e.g. great tits, Parus major: Slabbekoorn \& Peet 2003). Some species are also able to adjust the timing of their calls to avoid the noisiest times of the day, as in frogs (Lithobates clamitans and Lithobates catesbeianus) subjected to road traffic noise (Vargas-Salinas et al. 2014) and birds living adjacent to airports (Gil et al. 2015). There are also numerous cases where females demonstrate a preference for unexposed males compared to those exposed to a pollutant (Gore et al. 2018), although this mechanism is less useful in environments where all males are contaminated. There is evidence to suggest that such changes can impact ecosystem dynamics if some species are able to adapt to pollutants better than others. For example, in New Mexico, bird species that adjust vocalisations in response to noise pollution increased in number, while species unable to do this decreased, altering bird communities and species interactions (Francis et al. 2009). It is also worth noting that the ability of species to adapt to pollutants may be constrained when the pollutants relax sexual selection, as there is evidence that sexual selection may promote evolutionary mechanisms that allow organisms to cope with pollution (Jacomb et al. 2016).

When species are unable to adapt to reproductive challenges caused by pollution, the resulting population declines can have cascading effects on the wider ecosystem due to altered species interactions. For instance, following the decrease in fathead minnows due to EE2 exposure, Kidd et al. (2014) observed an increase in abundance of its prey species, such as zooplankton, chaoborus, and emerging insects, as well as a decrease in biomass of lake trout, a fathead minnow predator. These species were unaffected by direct oestrogen exposure, highlighting the need for research examining broader ecological effects, such as species interactions, when assessing environmental impacts of pollution (see also Windsor et al. 2018). Such cascading effects have also been seen in ecosystems where gastropod populations have declined due to exposure to anti-fouling paint, resulting in disruptions to intertidal community structure and function (Coray \& Bard 2007, Roach \& Wilson 2009).

\section{Future directions}

When investigating effects of environmental change, there is a tendency for studies to focus on the direct, short-term effects of a single pollutant on a single species, most often vertebrates (Lewis \& Ford 2012). However, this only provides a limited understanding of pollutant impacts and may underestimate broader hazards posed to wildlife and the ecological communities they inhabit. For a more holistic understanding, future studies should consider both biotic and abiotic interactions (discussed in Saaristo et al. 2018). Indeed, the previously mentioned research by Kidd et al. (2014) demonstrates the influence of species interactions on the wider effect of a pollutant, which can easily be overlooked when studying direct effects alone. Furthermore, pollutants can interact with other stressors to cause synergistic effects, where the interaction of multiple stressors causes an effect that is significantly greater than would be expected if the independent effects of each stressor were simply summed together. For example, in zebrafish, exposure to progestin and high temperatures simultaneously had much more severe negative impacts on female fecundity than either effect in isolation (Cardoso et al. 2017). Additionally, future research should investigate the effects of pollutants over multiple generations. Such research will help to uncover whether species are able to adapt or habituate to environmental changes and will help us understand how pollutants may otherwise impact evolutionary processes (Saaristo et al. 2018, Candolin 2019). More broadly, if we are to more fully understand 
the impacts of pollutants on reproduction, more focus needs to be given to integrating research across multiple spatial scales at different levels of ecological complexity, from controlled laboratory assays to field-based investigations under more natural settings (Klaminder et al. 2016, Windsor et al. 2018; e.g. mesocosm-based studies on light pollution: Bennie et al. 2015; fieldbased studies on noise pollution: Simpson et al. 2016; whole-lake experiments on chemical pollution: Kidd et al. 2007, 2014).

Our increasing awareness of the impacts of pollutants on reproduction should be harnessed to implement mitigation strategies to manage many of the deleterious effects outlined in our review. Such actions may not only be beneficial for the sustainability of wildlife populations, but also for human health, with mounting evidence that these pollutants can affect humans in a similar manner to other animals (Damgaard et al. 2002, Deng et al. 2016). Indeed, there has already been some progress towards improved management of pollutants. For example, additional treatment steps, such as ozonation and activated carbon treatment, can play a key role in the removal of EDCs and other contaminants from wastewater (Nowotny et al. 2007, Hollender et al. 2009). In the context of light pollution, limiting the use of artificial light, shielding lights to reduce 'trespass' of light into neighbouring areas, and altering the intensity or spectrum of lighting can decrease potential impacts of anthropogenic light at night (Gaston et al. 2012). It has also been suggested that sound barriers and noise curfews, which are already widely used to reduce impacts on human inhabitants, could be effectively employed to alleviate effects of noise pollution on wildlife (Slabbekoorn \& Ripmeester 2008). Such initiatives are just some of the many practical outcomes that can be achieved by harnessing research to minimise the detrimental effects of pollutants.

In this review, we highlight that environmental pollution, in its various forms, can interfere with many different aspects of reproduction, including physiology, gamete function, and organismal behaviour. These disruptions often reduce reproductive success of organisms by, for example, interfering with their ability to secure a mate or decreasing their fertility. In addition, pollution can reduce offspring viability through epigenetic effects or by altering reproductive timing (thereby causing a mismatch between ecological resources and offspring), by disrupting process of sexual selection resulting in mating with less suitable partners, and by disrupting parental care. While it is clear that environmental pollution can affect the reproduction of wildlife, the full extent to which these changes are affecting population growth, ecosystem structure, and evolutionary trajectories is less clear. To better understand these higher-level consequences of pollution, it is important that we collect long-term data and employ studies that incorporate increasing levels of ecological complexity through the use of mesocosmand field-based approaches, as well as continue to implement strategies to mitigate the impacts of pollution on wildlife and humans alike.

\section{Declaration of interest}

The authors declare that there is no conflict of interest that could be perceived as prejudicing the impartiality of this review.

\section{Funding}

B B M W was supported by the Australian Research Council (grant number DP190100642 and FT190100014). M G B and T B were supported by the Swedish Research Council Formas (2018-00828).

\section{Author contribution statement}

L C A, M G B, J M M and B B M W conceived the idea and developed the structure of the review with input from other coauthors. All authors contributed to the writing of the review.

\section{References}

Abascal FJ, Cosson J \& Fauvel C 2007 Characterization of sperm motility in sea bass: the effect of heavy metals and physicochemical variables on sperm motility. Journal of Fish Biology 70 509-522. (https://doi. org/10.1111/j.1095-8649.2007.01322.x)

André $M$, Solé $M$, Lenoir $M$, Durfort $M$, Quero $C$, Mas A, Lombarte A, Van der Schaar M, López-Bejar M, Morell M et al. 2011 Low-frequency sounds induce acoustic trauma in cephalopods. Frontiers in Ecology and the Environment 9 489-493. (https://doi.org/10.1890/100124)

Barber JR, Burdett CL, Reed SE, Warner KA, Formichella C, Crooks KR, Theobald DM \& Fristrup KM 2011 Anthropogenic noise exposure in protected natural areas: estimating the scale of ecological consequences. Landscape Ecology 26 1281-1295. (https://doi.org/10.1007/s10980011-9646-7)

Baroiller JF \& D'Cotta H 2001 Environment and sex determination in farmed fish. Comparative Biochemistry and Physiology: Toxicology and Pharmacology 130 399-409. (https://doi.org/10.1016/s15320456(01)00267-8)

Baron GL, Raine NE \& Brown MJ 2017 General and species-specific impacts of a neonicotinoid insecticide on the ovary development and feeding of wild bumblebee queens. Proceedings of the Royal Society of London: Series B 284 20170123. (https://doi.org/10.1098/rspb.2017.0123)

Beirão J, Litt MA \& Purchase CF 2018 Chemically-dispersed crude oil and dispersant affects sperm fertilizing ability, but not sperm swimming behaviour in capelin (Mallotus villosus). Environmental Pollution 241 521-528. (https://doi.org/10.1016/j.envpol.2018.05.080)

Ben Maamar M, Sadler-Riggleman I, Beck D, McBirney M, Nilsson E, Klukovich R, Xie Y, Tang C, Yan W \& Skinner MK 2018 Alterations in sperm DNA methylation, non-coding RNA expression, and histone retention mediate vinclozolin-induced epigenetic transgenerational inheritance of disease. Environmental Epigenetics 4 dvy010. (https://doi. org/10.1093/eep/dvy010)

Bennie J, Davies TW, Cruse D, Inger R \& Gaston KJ 2015 Cascading effects of artificial light at night: resource-mediated control of herbivores in a grassland ecosystem. Philosophical Transactions of the Royal Society of London: Series B 370 20140131. (https://doi.org/10.1098/ rstb.2014.0131)

Bernhardt ES, Rosi EJ \& Gessner MO 2017 Synthetic chemicals as agents of global change. Frontiers in Ecology and the Environment 15 84-90. (https://doi.org/10.1002/fee.1450) 
Bertram MG, Saaristo M, Baumgartner JB, Johnstone CP, Allinson M, Allinson G \& Wong BBM 2015 Sex in troubled waters: widespread agricultural contaminant disrupts reproductive behaviour in fish. Hormones and Behavior 70 85-91. (https://doi.org/10.1016/j. yhbeh.2015.03.002)

Bertram MG, Saaristo M, Ecker TE, Baumgartner JB \& Wong BBM 2018 An androgenic endocrine disruptor alters male mating behavior in the guppy (Poecilia reticulata). Behavioral Ecology 29 1255-1263. (https:// doi.org/10.1093/beheco/ary121)

Bird S \& Parker J 2014 Low levels of light pollution may block the ability of male glow-worms (Lampyris noctiluca L.) to locate females. Journal of Insect Conservation 18 737-743. (https://doi.org/10.1007/s10841-0149664-2)

Brown AR, Owen SF, Peters J, Zhang Y, Soffker M, Paull GC, Hosken DJ, Wahab MA \& Tyler CR 2015 Climate change and pollution speed declines in zebrafish populations. PNAS 112 E1237-E1246. (https://doi. org/10.1073/pnas.1416269112)

Brüning A, Hölker F, Franke S, Kleiner W \& Kloas W 2016 Impact of different colours of artificial light at night on melatonin rhythm and gene expression of gonadotropins in European perch. Science of the Total Environment 543 214-222. (https://doi.org/10.1016/j. scitotenv.2015.11.023)

Burgess MD, Smith KW, Evans KL, Leech D, Pearce-Higgins JW, Branston CJ, Briggs K, Clark JR, du Feu CR, Lewthwaite K et al. 2018 Tritrophic phenological match-mismatch in space and time. Nature Ecology and Evolution 2 970-975. (https://doi.org/10.1038/s41559-0180543-1)

Campos B, Pina B, Fernández-Sanjuán M, Lacorte S \& Barata C 2012 Enhanced offspring production in Daphnia magna clones exposed to serotonin reuptake inhibitors and 4-nonylphenol. Stage- and fooddependent effects. Aquatic Toxicology 109 100-110. (https://doi. org/10.1016/j.aquatox.2011.12.003)

Candolin U 2019 Mate choice in a changing world. Biological Reviews of the Cambridge Philosophical Society 94 1246-1260. (https://doi. org/10.1111/brv.12501)

Candolin U \& Wong BBM 2019 Mate choice in a polluted world: consequences for individuals, populations and communities. Philosophical Transactions of the Royal Society of London: Series B, Biological Sciences 37420180055 . (https://doi.org/10.1098/ rstb.2018.0055)

Cardoso PG, Rodrigues D, Madureira TV, Oliveira N, Rocha MJ \& Rocha E 2017 Warming modulates the effects of the endocrine disruptor progestin levonorgestrel on the zebrafish fitness, ovary maturation kinetics and reproduction success. Environmental Pollution 229 300-311. (https:// doi.org/10.1016/j.envpol.2017.05.090)

Carnevali O, Santangeli S, Forner-Piquer I, Basili D \& Maradonna F 2018 Endocrine-disrupting chemicals in aquatic environment: what are the risks for fish gametes? Fish Physiology and Biochemistry 44 1561-1576. (https://doi.org/10.1007/s10695-018-0507-z)

Cianchetti-Benedetti M, Becciu P, Massa B \& Dell'Omo G 2018 Conflicts between touristic recreational activities and breeding shearwaters: shortterm effect of artificial light and sound on chick weight. European Journal of Wildlife Research 64 19. (https://doi.org/10.1007/s10344-018-1178-x)

Cook LE, Finger BJ, Green MP \& Pask AJ 2019 Exposure to atrazine during puberty reduces sperm viability, increases weight gain and alters the expression of key metabolic genes in the liver of male mice. Reproduction, Fertility, and Development 31 920-931. (https://doi. org/10.1071/RD18505)

Coray C \& Bard SM 2007 Persistence of tributyltin-induced imposex in dogwhelks (Nucella lapillus) and intersex in periwinkles (Littorina littorea) in Atlantic Canada. Water Quality Research Journal 42 111-122. (https://doi.org/10.2166/wqrj.2007.014)

Crews D, Bergeron JM, Bull JJ, Flores D, Tousignant A, Skipper JK \& Wibbels T 1994 Temperature-dependent sex determination in reptiles: proximate mechanisms, ultimate outcomes, and practical applications. Developmental Genetics 15 297-312. (https://doi.org/10.1002/ dvg.1020150310)

Damgaard IN, Main KM, Toppari J \& Skakkebæk NE 2002 Impact of exposure to endocrine disrupters inutero and in childhood on adult reproduction. Best Practice and Research: Clinical Endocrinology and Metabolism 16 289-309. (https://doi.org/10.1053/beem.2002.0205)
De Jong M, Ouyang JQ, Da Silva A, van Grunsven RH, Kempenaers B, Visser ME \& Spoelstra K 2015 Effects of nocturnal illumination on lifehistory decisions and fitness in two wild songbird species. Philosophical Transactions of the Royal Society of London: Series B 37020140128. (https://doi.org/10.1098/rstb.2014.0128)

De Rosa M, Zarrilli S, Paesano L, Carbone U, Boggia B, Petretta M, Maisto A, Cimmino F, Puca G, Colao A et al. 2003 Traffic pollutants affect fertility in men. Human Reproduction 18 1055-1061. (https://doi. org/10.1093/humrep/deg226)

Deng Z, Chen F, Zhang M, Lan L, Qiao Z, Cui Y, An J, Wang N, Fan Z, Zhao X et al. 2016 Association between air pollution and sperm quality: a systematic review and meta-analysis. Environmental Pollution 208 663-669. (https://doi.org/10.1016/j.envpol.2015.10.044)

Desforges JP, Hall A, McConnell B, Rosing-Asvid A, Barber JL, Brownlow A, Guise De S, Eulaers I, Jepson PD, Letcher RJ et al. 2018 Predicting global killer whale population collapse from PCB pollution. Science $\mathbf{3 6 1}$ 1373-1376. (https://doi.org/10.1126/science.aat1953)

Dixit R, Wasiullah, Malaviya D, Pandiyan K, Singh U, Sahu A, Shukla R, Singh B, Rai J, Sharma P et al. 2015 Bioremediation of heavy metals from soil and aquatic environment: an overview of principles and criteria of fundamental processes. Sustainability 7 2189-2212. (https:// doi.org/10.3390/su7022189)

Dodson SI, Merritt CM, Shannahan JP \& Shults CM 1999a Low exposure concentrations of atrazine increase male production in Daphnia pulicaria. Environmental Toxicology and Chemistry 18 1568-1573. (https://doi.org/10.1897/1551-5028(1999)018<1568:LECOAl>2.3. $\mathrm{CO} ; 2)$

Dodson SI, Merritt CM, Torrentera L, Winter KM, Tornehl CK \& Girvin K $1999 b$ Dieldrin reduces male production and sex ratio in Daphnia galeata mendotae. Toxicology and Industrial Health 15 192-199. (https:// doi.org/10.1191/074823399678846574)

Dominoni DM, Quetting M \& Partecke J 2013a Long-term effects of chronic light pollution on seasonal functions of European blackbirds (Turdus merula). PLoS ONE 8 e85069. (https://doi.org/10.1371/journal. pone.0085069)

Dominoni D, Quetting M \& Partecke J 2013b Artificial light at night advances avian reproductive physiology. Proceedings: Biological Sciences 280 20123017. (https://doi.org/10.1098/rspb.2012.3017)

Efimova T 1977 Effect of warm water discharges from konakovo tps on sex cycles of fish in the Ivankovo reservoir. $\operatorname{Tr}$ VGBO 21 63-82.

Eggert C 2004 Sex determination: the amphibian models. Reproduction, Nutrition, Development 44 539-549. (https://doi.org/10.1051/ rnd:2004062)

Eliyahu D, Applebaum S \& Rafaeli A 2003 Moth sex-pheromone biosynthesis is inhibited by the herbicide diclofop. Pesticide Biochemistry and Physiology 77 75-81. (https://doi.org/10.1016/S0048-3575(03)00101-9)

Evans J, Wilson A, Pilastro A \& Garcia-Gonzalez F 2019 Ejaculate-mediated paternal effects: evidence, mechanisms and evolutionary implications. Reproduction 1 109-126. (https://doi.org/10.1530/REP-18-0524)

Farzadinia P, Bigdeli M, Akbarzadeh S, Mohammadi M, Daneshi A \& Bargahi A 2016 Effect of noise pollution on testicular tissue and hormonal assessment in rat. Andrologia 48 869-873. (https://doi. org/10.1111/and.12524)

Fisher HS, Wong BBM \& Rosenthal GG 2006 Alteration of the chemical environment disrupts communication in a freshwater fish. Proceedings: Biological Sciences 273 1187-1193. (https://doi.org/10.1098/ rspb.2005.3406)

Francis CD, Ortega CP \& Cruz A 2009 Noise pollution changes avian communities and species interactions. Current Biology 19 1415-1419. (https://doi.org/10.1016/j.cub.2009.06.052)

Fuentes M, Maynard J, Guinea M, Bell I, Werdell P \& Hamann M 2009 Proxy indicators of sand temperature help project impacts of global warming on sea turtles in northern Australia. Endangered Species Research 9 33-40. (https://doi.org/10.3354/esr00224)

Gallo A 2018 Toxicity of marine pollutants on the ascidian oocyte physiology: an electrophysiological approach. Zygote 26 14-23. (https:// doi.org/10.1017/S0967199417000612)

Gaston KJ, Davies TW, Bennie J \& Hopkins J 2012 Reducing the ecological consequences of night-time light pollution: options and developments. Journal of Applied Ecology 49 1256-1266. (https://doi.org/10.1111/ j.1365-2664.2012.02212.x) 
Gil D, Honarmand M, Pascual J, Pérez-Mena E \& Macías Garcia C 2015 Birds living near airports advance their dawn chorus and reduce overlap with aircraft noise. Behavioral Ecology 26 435-443. (https://doi. org/10.1093/beheco/aru207)

Giwercman A, Carlsen E, Keiding N \& Skakkebaek NE 1993 Evidence for increasing incidence of abnormalities of the human testis: a review. Environmental Health Perspectives 101 (Supplement 2) 65-71. (https:// doi.org/10.1289/ehp.93101s265)

Gore AC, Holley AM \& Crews D 2018 Mate choice, sexual selection, and endocrine-disrupting chemicals. Hormones and Behavior 101 3-12. (https://doi.org/10.1016/j.yhbeh.2017.09.001)

Gould JC, Leonard LS, Maness SC, Wagner BL, Conner K, Zacharewski T, Safe S, McDonnell DP \& Gaido KW 1998 Bisphenol A interacts with the estrogen receptor $\alpha$ in a distinct manner from estradiol. Molecular and Cellular Endocrinology 142 203-214. (https://doi.org/10.1016/s03037207(98)00084-7)

Govers LC, Harper AP, Finger BJ, Mattiske DM, Pask AJ \& Green MP 2019 Atrazine induces penis abnormalities including hypospadias in mice. Journal of Developmental Origins of Health and Disease 11 1-4. (https:// doi.org/10.1017/S2040174419000473)

Guillette Jr LJ, Gross TS, Masson GR, Matter JM, Percival HF \& Woodward AR 1994 Developmental abnormalities of the gonad and abnormal sex hormone concentrations in juvenile alligators from contaminated and control lakes in Florida. Environmental Health Perspectives 102 680-688. (https://doi.org/10.1289/ehp.94102680)

Guillette Jr LJ, Gross TS, Gross DA, Rooney AA \& Percival HF 1995 Gonadal steroidogenesis in vitro from juvenile alligators obtained from contaminated or control lakes. Environmental Health Perspectives 103 (Supplement 4) 31-36. (https://doi.org/10.1289/ehp.95103s431)

Guillette Jr LJ, Pickford DB, Crain DA, Rooney AA \& Percival HF 1996 Reduction in penis size and plasma testosterone concentrations in juvenile alligators living in a contaminated environment. General and Comparative Endocrinology 101 32-42. (https://doi.org/10.1006/ gcen.1996.0005)

Haeba MH, Hilscherová K, Mazurová E \& Bláha L 2008 Selected endocrine disrupting compounds (vinclozolin, flutamide, ketoconazole and dicofol): effects on survival, occurrence of males, growth, molting and reproduction of Daphnia magna. Environmental Science and Pollution Research International 15 222-227. (https://doi.org/10.1065/ espr2007.12.466)

Hammoud A, Carrell DT, Gibson M, Sanderson M, Parker-Jones K \& Peterson CM 2010 Decreased sperm motility is associated with air pollution in Salt Lake City. Fertility and Sterility 93 1875-1879. (https:// doi.org/10.1016/j.fertnstert.2008.12.089)

Han Y, Shi W, Rong J, Zha S, Guan X, Sun H \& Liu G 2019 Exposure to waterborne $\mathrm{nTiO} 2$ reduces fertilization success and increases polyspermy in a bivalve mollusc: a threat to population recruitment. Environmental Science and Technology 53 12754-12763. (https://doi. org/10.1021/acs.est.9b03675)

Hansen J, Sato M, Ruedy R, Lo K, Lea DW \& Medina-Elizade M 2006 Global temperature change. PNAS 103 14288-14293. (https://doi. org/10.1073/pnas.0606291103)

Hayes T, Haston K, Tsui M, Hoang A, Haeffele C \& Vonk A 2002a Herbicides: feminization of male frogs in the wild. Nature 419 895-896. (https://doi.org/10.1038/419895a)

Hayes TB, Collins A, Lee M, Mendoza M, Noriega N, Stuart AA \& Vonk A 2002b Hermaphroditic, demasculinized frogs after exposure to the herbicide atrazine at low ecologically relevant doses. PNAS 99 5476-5480. (https://doi.org/10.1073/pnas.082121499)

Hayes T, Haston K, Tsui M, Hoang A, Haeffele C \& Vonk A 2003 Atrazineinduced hermaphroditism at $0.1 \mathrm{ppb}$ in American leopard frogs (Rana pipiens): laboratory and field evidence. Environmental Health Perspectives 111 568-575. (https://doi.org/10.1289/ehp.5932)

Hayes TB, Stuart AA, Mendoza M, Collins A, Noriega N, Vonk A, Johnston G, Liu R \& Kpodzo D 2006 Characterization of atrazineinduced gonadal malformations in African clawed frogs (Xenopus laevis) and comparisons with effects of an androgen antagonist (cyproterone acetate) and exogenous estrogen (17 $\beta$-estradiol): support for the demasculinization/feminization hypothesis. Environmental Health Perspectives 114 (Supplement 1) 134-141. (https://doi.org/10.1289/ ehp.8067)
Hayes TB, Khoury V, Narayan A, Nazir M, Park A, Brown T, Adame L, Chan E, Buchholz D, Stueve T et al. 2010 Atrazine induces complete feminization and chemical castration in male African clawed frogs (Xenopus laevis). PNAS 107 4612-4617. (https://doi.org/10.1073/ pnas.0909519107)

Hollender J, Zimmermann SG, Koepke S, Krauss M, McArdell CS, Ort C, Singer H, von Gunten U \& Siegrist H 2009 Elimination of organic micropollutants in a municipal wastewater treatment plant upgraded with a full-scale post-ozonation followed by sand filtration. Environmental Science and Technology 43 7862-7869. (https://doi. org/10.1021/es9014629)

Hollows CF, Johnston EL \& Marshall DJ 2007 Copper reduces fertilisation success and exacerbates Allee effects in the field. Marine Ecology Progress Series 333 51-60. (https://doi.org/10.3354/meps333051)

Huang X, Zhang B, Wu L, Zhou Y, Li Y, Mao X, Chen Y, Wang J, Luo P, Ma J et al. 2019 Association of exposure to ambient fine particulate matter constituents with semen quality among men attending a fertility center in China. Environmental Science and Technology 53 5957-5965. (https:// doi.org/10.1021/acs.est.8b06942)

Jacomb F, Marsh J \& Holman L 2016 Sexual selection expedites the evolution of pesticide resistance. Evolution: International Journal of Organic Evolution 70 2746-2751. (https://doi.org/10.1111/evo.13074)

Jenkins TG, James ER, Alonso DF, Hoidal JR, Murphy PJ, Hotaling JM, Cairns BR, Carrell DT \& Aston KI 2017 Cigarette smoking significantly alters sperm DNA methylation patterns. Andrology 5 1089-1099. (https://doi.org/10.1111/andr.12416)

Jepson PD, Arbelo $M$, Deaville R, Patterson IA, Castro P, Baker JR, Degollada E, Ross HM, Herráez P, Pocknell AM et al. 2003 Gasbubble lesions in stranded cetaceans. Nature 425 575-576. (https://doi. org/10.1038/425575a)

Jezierska B, Lugowska K \& Witeska M 2009 The effects of heavy metals on embryonic development of fish (a review). Fish Physiology and Biochemistry 35 625-640. (https://doi.org/10.1007/s10695-008-9284-4)

Jobling S, Reynolds T, White R, Parker MG \& Sumpter JP 1995 A variety of environmentally persistent chemicals, including some phthalate plasticizers, are weakly estrogenic. Environmental Health Perspectives 103 582-587. (https://doi.org/10.1289/ehp.95103582)

Jobling S, Nolan M, Tyler CR, Brighty G \& Sumpter JP 1998 Widespread sexual disruption in wild fish. Environmental Science and Technology 32 2498-2506. (https://doi.org/10.1021/es9710870)

Jobling S, Beresford N, Nolan M, Rodgers-Gray T, Brighty GC, Sumpter JP \& Tyler CR 2002a Altered sexual maturation and gamete production in wild roach (Rutilus rutilus) living in rivers that receive treated sewage effluents. Biology of Reproduction 66 272-281. (https://doi.org/10.1095/ biolreprod66.2.272)

Jobling S, Coey S, Whitmore JG, Kime DE, Van Look KJ, McAllister BG, Beresford N, Henshaw AC, Brighty G, Tyler CR et al. 2002b Wild intersex roach (Rutilus rutilus) have reduced fertility. Biology of Reproduction 67 515-524. (https://doi.org/10.1095/biolreprod67.2.515)

Jobling S, Williams R, Johnson A, Taylor A, Gross-Sorokin M, Nolan M, Tyler CR, van Aerle R, Santos E \& Brighty G 2006 Predicted exposures to steroid estrogens in UK rivers correlate with widespread sexual disruption in wild fish populations. Environmental Health Perspectives 114 (Supplement 1) 32-39. (https://doi.org/10.1289/ehp.8050)

Johnson AC \& Williams RJ 2004 A model to estimate influent and effluent concentrations of estradiol, estrone, and ethinylestradiol at sewage treatment works. Environmental Science and Technology 38 3649-3658. (https://doi.org/10.1021/es035342u)

Jurewicz J, Dziewirska E, Radwan M \& Hanke W 2018 Air pollution from natural and anthropic sources and male fertility. Reproductive Biology and Endocrinology 16 109. (https://doi.org/10.1186/s12958018-0430-2)

Kidd KA, Blanchfield PJ, Mills KH, Palace VP, Evans RE, Lazorchak JM \& Flick RW 2007 Collapse of a fish population after exposure to a synthetic estrogen. PNAS 104 8897-8901. (https://doi.org/10.1073/ pnas.0609568104)

Kidd KA, Paterson MJ, Rennie MD, Podemski CL, Findlay DL, Blanchfield PJ \& Liber K 2014 Direct and indirect responses of a freshwater food web to a potent synthetic oestrogen. Philosophical Transactions of the Royal Society of London: Series B 369 20130578. (https://doi.org/10.1098/ rstb.2013.0578) 
Klaminder J, Hellström G, Fahlman J, Jonsson M, Fick J, Lagesson A, Bergman E \& Brodin T 2016 Drug-induced behavioral changes: using laboratory observations to predict field observations. Frontiers in Environmental Science 4 81. (https://doi.org/10.3389/fenvs.2016.00081)

Kowalska-Góralska M, Dziewulska K \& Kulasza M 2019 Effect of copper nanoparticles and ions on spermatozoa motility of sea trout (Salmo trutta m. Trutta L.). Aquatic Toxicology 211 11-17. (https://doi.org/10.1016/j. aquatox.2019.03.013)

Lahnsteiner F, Berger B, Kletzl M \& Weismann T 2005 Effect of bisphenol A on maturation and quality of semen and eggs in the brown trout, Salmo trutta f. fario. Aquatic Toxicology 75 213-224. (https://doi.org/10.1016/j. aquatox.2005.08.004)

Lange A, Paull GC, Coe TS, Katsu Y, Urushitani H, Iguchi T \& Tyler CR 2009 Sexual reprogramming and estrogenic sensitization in wild fish exposed to ethinylestradiol. Environmental Science and Technology 43 1219-1225. (https://doi.org/10.1021/es802661p)

Lapina N 1991 Effect of heat discharge from nuclear-power stations on the physiological-state of the female bleak Alburnus-Alburnus during spawning. Soviet Journal of Ecology 22 241-248.

Lewis C \& Ford AT 2012 Infertility in male aquatic invertebrates: a review. Aquatic Toxicology 120-121 79-89. (https://doi.org/10.1016/j. aquatox.2012.05.002)

Longcore T \& Rich C 2004 Ecological light pollution. Frontiers in Ecology and the Environment 2 191-198. (https://doi.org/10.1890/15409295(2004)002 [0191:ELP]2.0.CO;2)

Luksiene D \& Sandström O 1994 Reproductive disturbance in a roach (Rutilus rutilus) population affected by cooling water discharge. Journal of Fish Biology 45 613-625. (https://doi.org/10.1111/j.1095-8649.1994. tb00928.x)

Markman S, Leitner S, Catchpole C, Barnsley S, Müller CT, Pascoe D \& Buchanan KL 2008 Pollutants increase song complexity and the volume of the brain area HVC in a songbird. PLOS ONE 3 e1674. (https://doi. org/10.1371/journal.pone.0001674)

Mateo J, Smith A, Ong M \& Bono de JS 2014 Novel drugs targeting the androgen receptor pathway in prostate cancer. Cancer Metastasis Reviews 33 567-579. (https://doi.org/10.1007/s10555-013-9472-2)

Matthiessen P \& Gibbs PE 1998 Critical appraisal of the evidence for tributyltin-mediated endocrine disruption in mollusks. Environmental Toxicology and Chemistry 17 37-43. (https://doi.org/10.1002/ etc.5620170106)

Møller AP, Surai P \& Mousseau TA 2005 Antioxidants, radiation and mutation as revealed by sperm abnormality in barn swallows from Chernobyl. Proceedings: Biological Sciences 272 247-253. (https://doi. org/10.1098/rspb.2004.2914)

Møller AP, Mousseau TA, Lynnn C, Ostermiller S \& Rudolfsen G 2008 Impaired swimming behaviour and morphology of sperm from barn swallows Hirundo rustica in Chernobyl. Mutation Research 650 210-216. (https://doi.org/10.1016/j.mrgentox.2007.12.006)

Møller AP, Bonisoli-Alquati A, Mousseau TA \& Rudolfsen G 2014 Aspermy, sperm quality and radiation in Chernobyl birds. PLOS ONE 9 e100296. (https://doi.org/10.1371/journal.pone.0100296)

Murphy MB, Hecker M, Coady KK, Tompsett AR, Jones PD, Du Preez LH, Everson GJ, Solomon KR, Carr JA, Smith EE et al. 2006 Atrazine concentrations, gonadal gross morphology and histology in ranid frogs collected in Michigan agricultural areas. Aquatic Toxicology $\mathbf{7 6}$ 230-245. (https://doi.org/10.1016/j.aquatox.2005.09.010)

Nowotny N, Epp B, von Sonntag C \& Fahlenkamp H 2007 Quantification and modeling of the elimination behavior of ecologically problematic wastewater micropollutants by adsorption on powdered and granulated activated carbon. Environmental Science and Technology $4 \mathbf{1}$ 2050-2055. (https://doi.org/10.1021/es0618595)

Orr HA 2009 Fitness and its role in evolutionary genetics. Nature Reviews: Genetics 10 531-539. (https://doi.org/10.1038/nrg2603)

Park D, Hempleman SC \& Propper CR 2001 Endosulfan exposure disrupts pheromonal systems in the red-spotted newt: a mechanism for subtle effects of environmental chemicals. Environmental Health Perspectives 109 669-673. (https://doi.org/10.1289/ehp.01109669)

Qin ZF, Qin XF, Yang L, Li HT, Zhao XR \& Xu XB 2007 Feminizing/ demasculinizing effects of polychlorinated biphenyls on the secondary sexual development of Xenopus laevis. Aquatic Toxicology 84 321-327. (https://doi.org/10.1016/j.aquatox.2007.06.011)
Raptis CE, van Vliet MTH \& Pfister S 2016 Global thermal pollution of rivers from thermoelectric power plants. Environmental Research Letters 11 104011. (https://doi.org/10.1088/1748-9326/11/10/104011)

Roach AC \& Wilson SP 2009 Ecological impacts of tributyltin on estuarine communities in the hastings river, nsw Australia. Marine Pollution Bulletin 58 1780-1786. (https://doi.org/10.1016/j.marpolbul.2009.08.021)

Robert KA, Lesku JA, Partecke J \& Chambers B 2015 Artificial light at night desynchronizes strictly seasonal reproduction in a wild mammal. Proceedings: Biological Sciences 282 20151745. (https://doi. org/10.1098/rspb.2015.1745)

Rompala GR, Mounier A, Wolfe CM, Lin QS, Lefterov I \& Homanics GE 2018 Heavy chronic intermittent ethanol exposure alters small noncoding RNAs in mouse sperm and epididymosomes. Frontiers in Genetics 9 32. (https://doi.org/10.3389/fgene.2018.00032)

Rubes J, Selevan SG, Evenson DP, Zudova D, Vozdova M, Zudova Z, Robbins WA \& Perreault SD 2005 Episodic air pollution is associated with increased DNA fragmentation in human sperm without other changes in semen quality. Human Reproduction 20 2776-2783. (https:// doi.org/10.1093/humrep/dei122)

Russ A, Reitemeier S, Weissmann A, Gottschalk J, Einspanier A \& Klenke R 2015 Seasonal and urban effects on the endocrinology of a wild passerine. Ecology and Evolution 5 5698-5710. (https://doi.org/10.1002/ ece3.1820)

Saaristo M, Brodin T, Balshine S, Bertram MG, Brooks BW, Ehlman SM, McCallum ES, Sih A, Sundin J, Wong BBM et al. 2018 Direct and indirect effects of chemical contaminants on the behaviour, ecology and evolution of wildlife. Proceedings of the Royal Society of London: Series B 285 20181297. (https://doi.org/10.1098/rspb.2018.1297)

Scott A \& Vermeirssen E 1994 Production of conjugated steroids by teleost gonads and their role as pheromones. In Perspectives in Comparative Endocrinology 645-654. Eds Davey KG, Peter RE \& Tobe SS. Ottawa: National Research Council.

Selevan SG, Borkovec L, Slott VL, Zudová Z, Rubes J, Evenson DP \& Perreault SD 2000 Semen quality and reproductive health of young Czech men exposed to seasonal air pollution. Environmental Health Perspectives 108 887-894. (https://doi.org/10.1289/ehp.00108887)

Shannon G, McKenna MF, Angeloni LM, Crooks KR, Fristrup KM, Brown E, Warner KA, Nelson MD, White C, Briggs J et al. $2016 \mathrm{~A}$ synthesis of two decades of research documenting the effects of noise on wildlife. Biological Reviews of the Cambridge Philosophical Society 91 982-1005. (https://doi.org/10.1111/brv.12207)

Short AK, Yeshurun S, Powell R, Perreau VM, Fox A, Kim JH, Pang TY \& Hannan AJ 2017 Exercise alters mouse sperm small noncoding RNAs and induces a transgenerational modification of male offspring conditioned fear and anxiety. Translational Psychiatry 7 e1114. (https:// doi.org/10.1038/tp.2017.82)

Simpson SD, Radford AN, Nedelec SL, Ferrari MC, Chivers DP, McCormick MI \& Meekan MG 2016 Anthropogenic noise increases fish mortality by predation. Nature Communications 7 10544. (https://doi. org/10.1038/ncomms10544)

Skakkebæk NE, Meyts RD \& Main KM 2001 Testicular dysgenesis syndrome: an increasingly common developmental disorder with environmental aspects: opinion. Human Reproduction 16 972-978. (https://doi.org/10.1093/humrep/16.5.972)

Slabbekoorn H \& Peet M 2003 Ecology: birds sing at a higher pitch in urban noise. Nature 424 267-267. (https://doi.org/10.1038/424267a)

Slabbekoorn H \& Ripmeester EA 2008 Birdsong and anthropogenic noise: implications and applications for conservation. Molecular Ecology 17 72-83. (https://doi.org/10.1111/j.1365-294X.2007.03487.x)

Sone K, Hinago M, Itamoto M, Katsu Y, Watanabe H, Urushitani H, Tooi O, Guillette Jr LJ \& Iguchi T 2005 Effects of an androgenic growth promoter $17 \beta$-trenbolone on masculinization of mosquitofish (Gambusia affinis affinis). General and Comparative Endocrinology 143 151-160. (https:// doi.org/10.1016/j.ygcen.2005.03.007)

Soubry A, Hoyo C, Jirtle RL \& Murphy SK 2014 A paternal environmental legacy: evidence for epigenetic inheritance through the male germ line. BioEssays 36 359-371. (https://doi.org/10.1002/bies.201300113)

Sram RJ, Bene I, Binková B, Dejmek J, Horstman D, Kotěsovec F, Otto D, Perreault SD, Rubes J, Selevan SG et al. 1996 Teplice program - the impact of air pollution on human health. Environmental Health Perspectives $\mathbf{1 0 4}$ (Supplement 4) 699-714. (https://doi.org/10.1289/ehp.104-1469669) 
Suárez-Rodríguez M \& Garcia CM 2017 An experimental demonstration that house finches add cigarette butts in response to ectoparasites. Journal of Avian Biology 48 1316-1321. (https://doi.org/10.1111/jav.01324)

Tavera-Mendoza L, Ruby S, Brousseau P, Fournier M, Cyr D \& Marcogliese D 2002 Response of the amphibian tadpole (Xenopus laevis) to atrazine during sexual differentiation of the testis. Environmental Toxicology and Chemistry 21 527-531. (https://doi.org/10.1897/15515028(2002)021<0527:rotat $>2.0$. co;2)

Ten Hallers-Tjabbes CCT, Kemp JF \& Boon JP 1994 Imposex in whelks (Buccinum undatum) from the open North Sea: relation to shipping traffic intensities. Marine Pollution Bulletin 28 311-313. (https://doi. org/10.1016/0025-326X(94)90156-2)

Tomkins P, Saaristo M, Bertram MG, Michelangeli M, Tomkins RB \& Wong BBM 2018 An endocrine-disrupting agricultural contaminant impacts sequential female mate choice in fish. Environmental Pollution 237 103-110. (https://doi.org/10.1016/j.envpol.2018.02.046)

Valcarce DG, Vuelta E, Robles V \& Herráez MP 2017 Paternal exposure to environmental 17-alpha-ethinylestradiol concentrations modifies testicular transcription, affecting the sperm transcript content and the offspring performance in zebrafish. Aquatic Toxicology 193 18-29. (https://doi.org/10.1016/j.aquatox.2017.09.025)

Van Geffen KG, Groot AT, Van Grunsven RHA, Donners M, Berendse F \& Veenendaal EM 2015 Artificial night lighting disrupts sex pheromone in a noctuid moth. Ecological Entomology 40 401-408. (https://doi. org/10.1111/een.12202)

Vargas-Salinas F, Cunnington GM, Amézquita A \& Fahrig L 2014 Does traffic noise alter calling time in frogs and toads? A case study of anurans in Eastern Ontario, Canada. Urban Ecosystems 17 945-953. (https://doi. org/10.1007/s11252-014-0374-z)
Virbickas J, Astrauskas A, Luksiene D \& Misuniene D 1981 The effects of thermal power generation on fish populations. Acta Hydrobiologia Lituanica 2 16-37.

Visser ME, Holleman LJ \& Caro SP 2009 Temperature has a causal effect on avian timing of reproduction. Proceedings: Biological Sciences $\mathbf{2 7 6}$ 2323-2331. (https://doi.org/10.1098/rspb.2009.0213)

Walters MJ, Guralnick RP, Kleist NJ \& Robinson SK 2019 Urban background noise affects breeding song frequency and syllable-type composition in the Northern Mockingbird. Condor 121 1-13. (https://doi.org/10.1093/ condor/duz002)

Windsor FM, Ormerod SJ \& Tyler CR 2018 Endocrine disruption in aquatic systems: up-scaling research to address ecological consequences. Biological Reviews of the Cambridge Philosophical Society 93 626-641. (https://doi.org/10.1111/brv.12360)

Wong BBM, Tuomainen U \& Candolin U 2012 Algal blooms impact the quality of nest construction in three-spined sticklebacks. Animal Behaviour 84 1541-1545. (https://doi.org/10.1016/j.anbehav.2012.09.031)

Yow DM 2007 Urban heat islands: observations, impacts, and adaptation. Geography Compass 1 1227-1251. (https://doi.org/10.1111/j.17498198.2007.00063.x)

Received 22 March 2020

First decision 24 April 2020

Revised manuscript received 14 May 2020

Accepted 20 May 2020 